\title{
CHINA BECOMING A TECHNOLOGICAL SUPERPOWER - A NARROW WINDOW OF OPPORTUNITY
}

\author{
by \\ Jon Sigurdson \\ Working Paper No 194 \\ June 2004
}

Postal address: P.O. Box 6501, S-113 83 Stockholm, Sweden. Office address: Sveavägen 65

Telephone: +4687369360 Telefax: +468313017 E-mail: japan@hhs.se Internet:

http://www.hhs.se/eijs 
Jon Sigurdson

June 112004

\section{China Becoming a Technological Superpower - A Narrow Window of Opportunity}

\section{Summary}

This working paper shows China's technological advance, its basis in using foreign technology combined with its own manpower resources, and its clever integration of regional ambitions with national policies and programs. It also indicates an emerging global rivalry as China moves towards a future status as technological superpower.

In any attempt to understand recent and future industrial and economic development in China it becomes unavoidable to think about its various regions as the equivalents of major countries in other parts of the world. In several ways the regions of the Pearl River Delta, the Yangtze River Delta and the Bo-Hai Rim, including Beijing, can be compared with France, Germany and the UK in Europe. By world standard the regions essentially have middle-income purchasing power.

The US in the early part of this century remains unchallenged in defense, economics, politics and technology. Japan can be termed a superpower in economics and technology. $\mathrm{EU}$ is conceived as a superpower in economics, politics and technology, while Russia has remaining strengths in defense and technology. Today China is a superpower in politics with an emergence in economics and great ambitions in technology.

China has during the past ten years dramatically increased the number of students in tertiary education and provided more funding for R\&D, not only in absolute terms but also in relation to its GDP. Traditional indicators, such as patents, still suggest that China is far from reaching its goal of becoming a knowledge-based economy. However, monitoring signs of dynamic changes within industrial sectors and emerging competencies in a number of research fields brings forward a much more optimistic scenario.

JEL codes

O14, O15, O18, O19, O31, O32, O33, O34, P16, P31, R12

Keywords

technological superpower, regional innovation system, RIS, national S\&T program, global innovation system, 863, 973, Spark, Torch, China, standards in competition, TCL, ZTE, Huawei 


\title{
China Becoming a Technological Superpower - A Narrow Window of Opportunity ${ }^{1}$
}

\author{
$\underline{\text { Table of contents }}$
}

$\begin{array}{lr}\text { Chinese companies as global players } & 2 \\ \text { Technological aspirations - Narrow Window of opportunity } & 5 \\ \text { Regional Innovation Systems } & 7 \\ \text { Moving up the technological ladder - Standards in Competition } & 11 \\ \text { Creating and using brainpower - The Role of Universities } & 13 \\ \text { National Programs - National Science and Technology Policy } & 16 \\ \text { Global Rivalry - Competition and Cooperation } & 20 \\ \text { China - A Knowledge Economy } & 22 \\ \text { Bibliography } & 24\end{array}$

\section{Chinese companies as global players}

In late April 2004 a Chinese company, TCL Communication with its origin 1981 in Guizhou in South China, and Alcatel in France signed an agreement to combine their mobile handset resources into a joint venture company. The JV will include research and development, sales and distribution of mobile phone handsets and related products and services. The formation of the JV involves contributions with 55 million euros by TCL Communication and 45 million euros by Alcatel, thus TCL being the major shareholder that expects the partner to provide a platform to rapidly expand international business.

TCL started as a manufacturer of tape recorders and became reorganized after having coped with a financial crisis in 1986 and developed into an important trader in TV sets and subsequently listed on the Shenzhen Stock Exchange in 1993. In 2000 TCL started new production lines for TV sets and entered into mobile handsets the following year. In 2002 the TCL Group invited strategic investors from abroad and made important changes in its management structure.

Alcatel has through its acquisition of the ITT partnership in the Shanghai Bell telecommunications company been a pioneer in providing advanced digital switches to China. The present Alcatel owes its origin to a company that was started in 1888 as a general electrical equipment factor, CGE, to follow the trails of Siemens in Germany and General Electric in the US. The company is now specialized in telecommunications with

\footnotetext{
${ }^{1}$ This Working Paper has been prepared while being Visiting Senior Research Fellow at the East Asian Institute in Singapore during the summer of 2004. I am very grateful for having been invited to prepare a book manuscript for which this WP represents an early and partial outline for a book that carries the same title - to be published in 2005. I also want to express my appreciation to Professor Denis Simon of the Renssaeler Polytechnic Institute for his intellectual support for some of the concepts that are discussed. Furthermore I am very grateful to Dr Krystyna Palonka, of the European Institute of Japanese Studies at the Stockholm School of Economics, who tirelessly and without losing interest has identified many ambiguities and constantly improved the manuscript to make it more reader-friendly.
} 
a focus on solutions rather than manufacturing. The company has since the early $2000 \mathrm{~s}$ experienced difficulties in making its mobile handsets business profitable.

Only in 1999 information from the Ministry of Information Industry in Beijing indicated that domestic makers captured a miniscule 2 per cent of the market for mobile handsets. This share increased to about 55 per cent in 2003, a development for which companies like TCL, Bird, Konka and Lenovo have been responsible. This dramatic expansion over the past five years has its roots in China being able to enter into a global technological system. Many Chinese companies have entered into dynamically evolving learning processes where they have rapidly been acquiring manufacturing and design technologies. Such companies are now entering a stage where they are aggressively looking for resources that will enable them to become global players.

The TCL-Alcatel deal coincided with the visit of Premier Wen Jiabao in France but is hardly related to any initiatives or direct support from the Chinese government. TCL had already in late 2003 signed an even more important agreement with Thomson, also in France, to form another joint venture in which TCL will moreover be the dominant partner. The new company will become the world's largest producer of color TV. One year earlier TCL also bought Schneider, an ailing electronics company in Germany. TCL is majority partner in all mentioned new ventures and in this way the Chinese company has gained access to technology and well recognized brand names - Alcatel for handsets worldwide, RCA for TV sets in the US and Thomson in Europe. There is no doubt that liquid/crystal and plasma displays will eventually replace most TV sets using cathoderay-tubes (CRT) and TCL has declared that it will be one of the major global suppliers of digital TV sets.

In the meantime another Chinese company is carving out a major share in the manufacturing of CRTs. A state-owned producer of the TV glass bulbs based in Anyang in the North of Henan province, Ancai Group, has done a series of aggressive mergerand-acquisition deals in China as well as in the US. Ancai in the second half of 2003 acquired all plant and equipment from the joint venture between Asahi Glass and Corning in the US. When in operation in China the transformed plant will have an annual production of six million glass bulbs for TV CRTs of 25 inches and larger. Ancai is making these daring moves when Japanese companies are hesitant to continue its investment in a technology that will eventually disappear. The company argues that TV sets with traditional CRT will for quite some time secure market shares, particularly in developing countries. Ancai is posed to become the world's largest and the major producer of CRT glass tubes which includes a joint venture with LG-Philips located in the Zhengzhou, the capital of Henan province. Thus its annual production will amount to 60 million tubes.

Apparently, industrial circles in China are well aware that major technological changes are underway, and are looking for ways to speed up the process inside China. Creating brand names and acquiring technology for Chinese products can be speeded up by joining forces with foreign companies or outright buying of foreign companies that have encountered serious economic difficulties. This was the case when Beijing Oriental 
Enterprise (BOE) in 2002 purchased the flat panel division from Hynix, formerly Hyundai Electronics, when creditors forced the Korean company to offload its non-core activities. BOE and another Shanghai company are already in advanced investment stages to create major manufacturing capability for flat-screen panels.

BOE was in the 1950s an electronics company that was serving the military sector. It suffered serious financial problems in the early 1990s in its attempts to adjust in the new business climate that came into being after China announced its Open-Door-Policy and speed up the economic reform process. BOE was reorganized in 1993 - with employees also providing investing - and was listed on Shenzhen Stock Exchange in 1997. The product range has shifted from traditional electronics components to high-tech communications, computer and digital systems with a current focus on the new generation of display devices. In Beijing BOE is making a major investment in a production plant for flat panel displays, while SVA in Shanghai is in cooperation with NEC in Japan also making a similar large/scale investment.

Although already successful, Chinese companies are not always commonly recognized as global actors. This is still the situation for China International Marine Container Group (CIMC), based in Shenzhen that has become a major supplier in the global market for marine shipping containers. Its growth has been driven by the acquisition of container manufacturing facilities scattered along coastal China from Dalian in the North down to the Pearl River Delta, including a major manufacturing facility in Shenzhen. Similar to most large companies in China CIMC is still state-owned but operates under stringent operational and financial control by group management ${ }^{2}$.

These moves are demonstrating a multi/thronged approach by companies and government to give China leverage and strengthen its technological position in the global market place which the country re-entered only in the late 1970s. China has become the industrial hub of the world and her products now reach every corner of the world. Foreign direct investment, booming export markets and a large domestic market have together with abundant labor and improving infrastructure been driving an explosive growth of manufacturing.

Meanwhile, while quality is constantly going up the prices of China's manufactured goods are going down. China's terms of trade for its industrial products are much less favorable than was the case for Japan and Korea in their early industrialization efforts. China yet has to capture brainpower industries in a major way, without it will be stuck with low levels of added value in their exported products.

\footnotetext{
${ }^{2}$ Meyer, Marshal W. \& Lu Xiaohui, Managing Indefinite Boundaries: The Strategy and Structure of a Chinese Business Firm, Management and Organization Review (2004) 1:1 1-30
} 


\section{Technological aspirations - Narrow Window of opportunity}

Lester Thurow in 1997 noted that the global economic system is simultaneously affected by movements of five tectonic plates: the end of communism; a technological shift to an era dominated by man-made brainpower industries; a demography never before seen; a global economy; and an era where there is no dominant economic, political or military power.

To a great extent China has become part of this aggravating shift and is left with a narrow window of opportunity to again become a leading nation - a technological superpower. China has been living with a frustration since the industrial revolution took off in Europe and left the nation outside the mainstream of technological mastery where in the past only Japan in Asia was able to breakout out of a self-imposed straitjacket. Japan has in more recent times been trailed by Korea and other countries while China was contained within a planned economy.

The industrialization of Communist China that started in the early 1950s, supported by the then Soviet Union, made a successful break with China's backwardness. A substantial number of strategic industrial complexes were built, many of them in the Northeast provinces which had until 1945 been under Japanese occupation - formerly known as Manchuria. However, an ideological fixation and rashness to catch up with the outside world led to the disaster of the Great Leap Forward. China eagerly wanted to catch up with Great Britain in steel production as USSR announced its goal of overtaking the US in this sector. The successful collectivization of agriculture in its early stages made the leadership believe that rural labor could easily and quickly be transferred to industrial production. This proved to be a grim mistake and the expected rapid industrialization resulted in dismal failure and most industrial products of the Great Leap Forward were completely useless.

In an ensuing power struggle with its roots in ideology China at the times of the Cultural Revolution almost reached the stage of civil war. During this period China attempted major reforms of its innovation system, reorganized research institutes and universities; although with more attention to ideological dedication than results that would support the country's technological and scientific modernization. The situation was further complicated by the real or perceived threat of a military conflict, possibly involving nuclear weapons, with the US that was at the time heavily involved in its war in Vietnam. This forced the planners in China to relocate major industries of importance for tits defense capabilities to the interior of China in order to reduce its vulnerability.

It took until the end of the 1970s before China could anew establish its modernization goals; this time exploiting foreign capital and foreign technology. The process started modestly after the Open-Door-Policy had been announced in 1978. The size of potential markets in China, the seriousness of the leadership and rapidly changing economic conditions eventually persuaded the outside world that China was going to become part of the world economy. Throughout the previous period of almost 30 years Mao Zetong 
remained until his death in 1976 the dominant political leader with at times a truly formidable power. He sought to change the character of the Chinese people by inspiring them to heroic deeds while in parallel tormenting them through his ambitious but unrealistic goals of quickly modernizing the nation. Still Mao remains the icon of a united China, where his party remains in power although almost all his policies have been abandoned

In the meantime China in 1979 introduced a family planning program that drastically reduced family size with its very strong emphasis on one-child family and measures to ensure its success. The population would today have been 1,600 million instead of 1,300 if China had not followed this course. However, China, like industrialized countries in Europe and Japan, will rapidly become an aging society and the working-age population will begin to shrink already around 2015 .

The median age of the population will climb from 32 in 2003 to around 45 in 2040. As an aging society China is not only facing a financial predicament as it is now evolving in Europe and Japan. The leadership has to cope with at least two emerging challenges. First, the country must get rich hurriedly in order to be able finance the costs of an aging population in terms of health care and other social security needs. Second, China being still in the stage of initial development must move swiftly to fully utilize its still young people to, without any delay, raise all levels of knowledge which would be required in a more mature industrialized society.

China's narrow window of opportunity compels it to vigorously and forcefully use youngish entrepreneurs, engineers and scientists to move the country to the high pinnacles of economic development before the population gets old and tired and has not only to financially be cared for. Thus, brainpower industries have to replace the laborintensive industries that still dominate most industrial sectors in China. Brainpower industries require talented people, technological ideas, advanced knowledge, sophisticated infrastructure, financial capital and other resources. This book offers facts and insights on how China is mobilizing such resources to become a technological superpower.

The world of today has only one superpower. The US is in the early part of this century unchallenged in defense, economics, politics and technology. Japan can be termed a superpower in economics and technology. EU is conceived as a superpower in economics, politics and technology, while Russia has remaining strengths in defense and technology. Today China is a superpower in politics with an emergence in economics and great ambitions in technology. The process of achieving rapid technological progress and reaching the status of a technological superpower has been the substance of the deliberations of thousands of scientists, engineers and policy makers that have since early 2003 been preparing the 2020 Science and Technology Plan ${ }^{3}$.

The 2020 Plan covers altogether twenty different but also closely related features. Manufacturing is one of them for which the Chinese Academy of Engineering (CAE) has

\footnotetext{
${ }^{3}$ Author interviews and Beijing conference participation, November 2003.
} 
been given the mandate of coordinating views on China's future course in industrial development. Basic research is naturally the responsibility of the Chinese Academy of Sciences (CAS), while the State Defense Science and Technology Commission are considering China's future in military technology. The National Research Centre for Science and Technology for Development (NRCSTD) is shouldered with the task of bringing all various opinions and views into an overall strategy for China to reach its ambitious goals by 2020. The Centre has also been given the special task of charting the course of China's regional innovation systems (RIS)

In any country, and particularly in a country like China with its extraordinary size and diversity, technological innovation will take place in a number of its regions that are becoming spatial innovation systems. External connections to other businesses, to component suppliers and to researchers are as important for these regions as internal ones.

\section{Regional Innovation Systems}

The dynamic changes that erupted from economic policies since the late 1970s have formed new industrial structures along China's coastal areas and also in a major way transformed the economic relations between the centre and the regions/provinces. The regionalization that has taken place prompts us to view China as a federation of economies rather than a completely integrated economic entity, and similar tendencies can also be identified in other countries. The result is that regions interact more with agents from outside the country than within. These regions have become innovative with their own distinctive ambitions to foster their industrial dynamics and development which need to be supported by regional policies for institutional and structural changes although also supported for by national structures. Furthermore, it has also been practicable for the planners to create different approaches towards innovation in some technology sectors for which the size of China offers more local and regional possibilities than would be feasible in most other regions of the world.

It has for some time been possible to identify three regions in China where policies and structures reflect an ongoing regionalization that also includes science and technology as essential components. One is the Yangtze River Delta (YRD) region which includes Shanghai and 14 other cities in the southern part of Jiangsu Province and the northern part of Zhejiang Province - close to the actual river delta. The population of the YRD region is presently 82 million which corresponds to about 81 per cent of the population of the two provinces combined with Shanghai. A second distinctive region is the Pearl River Delta (PRD) region which includes Guangzhou (Canton) and Shenzhen, Hong Kong and Macao and a several closely linked cities in Guangdong province. The population of the PRD region is now 48 million. A third region, towards the north, still along China's coastal line, less clearly defined but also very important, is the Bo-Hai Rim (BHR). This includes Beijing with its surrounding areas and Tianjin on the coast, parts of Hebei province and Qingdao, Weihai and Yantai Shandong province - with a population of around 80 million. These three regions share three per cent of China's land mass and 
have about 15 per cent of the country's population, while generating 45 per cent of gross domestic product and more than 70 per cent of international trade and investment.

First two regions are important hubs in China having become the manufacturing centre of the world. PRD and YRP have developed into the heaviest concentrations of industrial activities that can be found anywhere in the world. The Pearl River Delta started its race earlier and has reached a GDP of US\$267 billion compared with US\$205 billion for the Yangtze River Delta region - 2001. PRD is also dominating with its exports of US\$195 billion against US\$74 billion for YRD - in 2001.

In any attempt to understand recent and future industrial and economic development in China it becomes unavoidable to think about various regions as the equivalents of major countries in other parts of the world. In several ways the regions of the Pearl River Delta, the Yangtze River Delta and the Bo-Hai Rim can be compared with France, Germany and the UK in Europe. By world standard the regions essentially have middle-income purchasing power. However, income levels within the region show great discrepancies which reflect a multi-level industrial structure including large sectors of labor-intensive manufacturing. Labor resources for the continued existence of such industries within the regions rely on large numbers of migrant workers who in Chinese statistics are recognized as "the floating population".

The Facts \& Figures Annual Handbook for 2003 declares that with constant development in China's economy more and more people are leaving their registered permanent residence to seek better jobs. The State Statistics Bureau states that China's floating population has exceed 120 million in 2002, although the official figure is likely to considerably underestimate the real numbers.

Until now, still most migrant workers move within provinces while a figure of transprovincial floating population is only 42 million. Naturally, poor and populous provinces offer more migrant workers. Sichuan provides 16\%, Anhui and Hunan each 10, Jiangxi $9 \%$, Henan and Hubei each $7 \%$ according to the officially announced numbers. The outflow from these six provinces makes up 59 per cent of the national trans-provincial floating population. Six provinces and two municipalities (Shanghai and Beijing) are the most attractive locations with Guangdong province absorbing 36\%, Zhejiang 9\%, Shanghai $7 \%$, Jiangsu 6\%, Beijing 6\% and Fujian 5\% - of trans-provincial migrants.

Although Guangdong province still remains the magnet for many migrant workers some segments of the Pearl River Delta region, and similarly other more developed regions, are rapidly advancing. In the late 1970s at the location of the present industrial Shenzhen City only a small town with some 50,000 inhabitants existed. Only one engineer was reported and no industrial base whatsoever existed. Shenzhen was at the time just the frontier of a booming Hong Kong. China's Open-Door-Policy in 1979 completely changed the city conditions and Shenzhen has over the past couple of decades become a high-tech industrial city, with a population of seven million. 
Shenzhen is today the most multicultural city in China, developing at high speed with great flexibility. Forty per cent of the present inhabitants come from Guangdong. The rest comes from Hong Kong, Taiwan and all other parts of China. The expansion of production has been followed by research activities in which IT companies dominate. Exports from Shenzhen have increased rapidly during the past ten years and today about one third of China' high-tech exports originate in Shenzhen and in this respect Shenzhen is becoming more important than Beijing.

Shenzhen's characteristics include prominence in IT, finance and logistics. IT products constitute $90 \%$ of industrial output with an expected rapidly increasing share for biotechnology. Shenzhen companies have established a strong position in telecom switching equipment and in magnetic and optical reading heads. Two companies are looming on the horizon as serious competitors to the established European telecom companies like Ericsson and Siemens, US Motorola and Japanese NEC - not only in domestic but also in global markets.

The most prominent one is the still privately-held Huawei Technologies being closely trailed by other domestic competitors. A second one is ZTE Corporation that when established in 1985 was only a simple trading company, under the name Zhongxing Semiconductor, having been sponsored by the No. 691 Factory under former Ministry of Aerospace Industry. ZTE entered the telecom sector in the early 1990s when domestic demand increased rapidly and management found that engineering competence inside the company provided a golden opportunity to enter a new and rapidly expanding industrial sector. In many other fields Shenzhen shows rapid advances in industrial technologies .For example an expansion of technological competence within innovative materials has driven rapid developments of production technology for new types of advanced high-tech batteries.

Foreign companies have in the past located in Shenzhen because of labor which is not only attractive for cost reasons but also for its increasing competence levels. Recently, a new reason for the increasing attractiveness of Shenzhen lies in its dominance of private companies while industry in many other Chinese cities is dominated by state-owned enterprises (SOEs). As a consequence more than 90 per cent of all R\&D carried out in Shenzhen takes place inside the companies. Incubators have in recent years taken on a prominent role for which private firms are mainly responsible. The government policy is focused on providing finance for incubators, and a favorable institutional and legal framework

The industrial output of Shenzhen will by 2020 - the local government states - increase seven-fold. The same optimism suggests that by 2020 semiconductors will become a very important part of the information technology structure in Shenzhen, and new materials and biotechnology will become leading.

Probably, one of the justifications for this optimism is University Town was designated in December 2003 to have 10,000 students of which 70\% being Shenzhen all-day students while the rest are "local" part-time students who study in evenings and on weekends. The 
University Town will in particular draw on resources from Tsinghua University, Beijing University, Harbin Engineering University and Nankai University. Shenzhen does not have a well developed university structure, although University Town is part of China's 211 Project whereby China should have the 100 best universities in the $21^{\text {st }}$ Century.

Halfway between Shenzhen and Guangzhou lies Dongguan which has a total population of 6.5 million of which only 1.5 million are permanent residents. The remainder consists of migrant workers of which some have become semi-permanent residents. Similar to Shenzhen, having moved through several stages of manufacturing, technology development, venturing, and high-technology development, Dongguan will in the future emphasize industrial development of biotechnology and other high-technology fields.

A first factory moved from Hong Kong (HK) to Dongguan in 1978 to start manufacture of handbags, soon followed by a large number of other HK firms that moved their laborintensive manufacturing onto the Mainland. The first companies from Taiwan moved to Dongguan in the mid-1980s, soon to be followed by a substantial number of electronics firms which created the foundation for Dongguan to gradually evolving into a high-tech industrial city. As a consequence Dongguan has attracted more and more high-tech industries - also from Europe, Japan and Singapore. Nokia started its production of telecom equipment here in the mid-1990s.

Dongguan authorities have realized that land is overloaded with too many labor-intensive companies scattered throughout, which among others created environmental problems. Thus, a conclusion was reached by municipal authorities that industrial development, population and environment must be harmonized, and further industrial development should be concentrated only on high-tech industries with considerable restrictions on others. This has eventually created a Dongguan focus on industries in the electronics and telecommunications sectors that increased their share of industrial employment from $17 \%$ in 1995 to $34 \%$ in 2000 . As a consequence industrial production has become more diversified and less labor-intensive. Dongguan has in parallel been expanding and reorganizing its higher education and is also establishing a science and industrial park. Published information on Songshan Lake Science \& Technical Industrial Park makes the following statement ${ }^{4}$.

Dongguan has set the strategic goal to become a modern industrial city noted for its manufacturing in the new millennium. It is a crucial decision to develop Songshan Lake Sci. \& Tech. Industrial Park (SSL) aiming at achieving the goal. In the future development of Dongguan's economy, as the economic and technological centers of this city, SSL will be the new platform for foreign economic and technical cooperation, the driver of upgrading the industrial structure, the centre of industrial supportive services.

Within the three regions mentioned above China is shaping regional competence blocks in other contexts referred to as regional innovation systems - which are increasingly interacting on a global scale, whereby China's national innovation system sometimes

\footnotetext{
${ }^{4}$ Songshan Lake Sci. \& Tech. Industrial Park - Innovation Chapter; Administrative Committee Building, Dongguan City, Guangdong, PRC, Tel. +86 - 7692891 228, fax: +86 - 7692822 822; www.ssl.gov.cn
} 
takes on a subordinated role. A competence block would include a set of competencies that are essential to successfully generate, identify, expand and exploit business ideas. The overwhelming concentration of shoe manufacture in Dongguan city in Guangzhou province offers an example of a competence block that has evolved in less than 20 years. Embedded competencies exist in clusters which have become endowed with synergetical structures of customers, inventors and innovators, entrepreneurs and industrialists. A competence bloc becomes fully operational, or complete, when it has a critical mass of activities, which attract competent actors for all its functions. Such competence blocks are these days coming into existence all over China.

However, it would be reasonable to consider China's late industrialization in the light of what took place in Europe two hundred years earlier. The industrial revolution took off in England in the late 1700s and swiftly crossed over to the European continent in the following century where it quickly embraced France and Germany also to become industrial powers. The industrial revolution in Europe not only created dominance on the rest of the world but also dramatically changed the power relations which started intensive rivalries among the European nations and social struggles within. The ensuing instability, resentment and envy contributed to the two world wars that started in Europe.

China today is undergoing, to some extent, a dynamic industrialization and modernization process on a land area that constitutes a continent and is larger and more populous than Europe. Industrialization in China started earlier but the very rapid and dynamic process that we are now witnessing started only some twenty years ago. This recent industrial revolution took off in the south of China, in Guangdong with its now industrialized cities and has been progressing northward along the coastal line and more recently to the interior of China. Pulsating industrial efforts have created great disparities between regions and social tensions which in certain aspects replicate early industrialization in Europe, with the significant difference that China is one nation. However, uneven speed of modernization in various parts of the country challenges the central government to alleviate disparities and control the leading regions not to become too autonomous. Ways of handling disparity issues in the ongoing industrialization process would reveal the aptitude of the central government to handle some of the country's most touchy problems.

\section{Moving up the technological ladder - Standards in Competition}

China's industrial development that fuelled its success in exports has been based on Chinese abundant labor offered at low cost to foreign investors as well as domestic companies. Many and soon most of world advanced consumer electronics products would be manufactured in China but rarely they carry a Chinese brand name or contain advanced technology of Chinese origin.

Standardization has in recent years become a very important element of China's technology strategy. There are basically two trends to consider - in the light of the tectonic shift of electronics to East Asia. One is the rising attempts to harmonize interests 
and development among three countries in East Asia - China, Japan and Korea. It has become obvious that the countries in East Asia have identified common interests and a more formal approach was established at a ministerial meeting in Seoul in September $2003^{5}$.

The other and more important trend is that China wants to establish its own technological platform, in as many areas as possible, in order to gain independence from foreign hightech companies and drastically reduce the level of license fees. Being able to establish or influence global standards has become very vital for national technological efforts.

This situation can only be changed gradually and needs to involve both company forays and government initiatives. The recent emphasis on industrial standards should be seen in this context - although China earlier registered a success with the International Telecommunications Union by having its own $3 \mathrm{G}$ standard accepted as one of three ITU global standards. Today almost all DVD players, bought anywhere in the world, are manufactured in China using technology for which mainly Japanese companies hold the intellectual property rights (IPR). Chinese companies in 2003 reached an agreement with the Japanese IPR owners who request hefty license fees. Presently the Japanese IPR holders of DVD technology have persuaded most of Chinese DVD makers to pay license fees at the level of $4 \%$ of ex-factory price.

China's IPR position is still feeble. The patent portfolio of Chinese companies in the US is very weak and the majority of patents granted in China - by Chinese Patent Office - are still held by foreign-based companies. The Chinese government wants to change this situation and so do domestic companies. New approaches to standards will enable a greater share of Chinese IPR and less license fees - and also greater possibilities to go globally. China has singled out a number of areas in which in wants to influence the process of setting international standards

China wishes to establish IT standards and will use the combined forces of R\&D and standard-setting to create changes for its IT sector in order to raise the level of technological development and avoid paying high license fees. Chinese companies have recently suffered as they have been faced with complaints from IPR holders in Japan and the US.

Thus Chinese government is today strongly supporting the development of various industrial technology standards in a number of areas which include digital TV and the controversial Chinese (WAPI) protocol for W-LAN that offers higher security but highly angered both the US and Japan.

TV services in China are still analogue and cable networks are very popular. Most likely digital services will be introduced soon and will be distributed both over cable and broadcasting networks. The US standard dominates in many countries, although China originally decided to base itself on the EU standard and was expected to pay license fees. However, introduction has been delayed and presently there is no competition from the 
outside. China would be able to choose between two different domestic approaches from an original array of five different ones.

In December 2003 China made an announcement on its plans for WAPI and on January 1 2004 announced that all production in China and all imports must conform to the Chinese WAPI standards. This made the US government angry and the US Trade Representative visited China for serious discussions - in February 2004.

WAPI involves both security and economic concerns. A number of personal digital assistants (PDAs), notebook computers and mobile handsets already have built-in WiFi, based on the original US standard that until recently been followed all over the world. Japan also shares the political and commercial concerns of the US as all Japanese companies buy the WiFi chipsets from US companies, where Intel has a strong position.

China's conditions was that if foreign companies want to deliver products to be sold in China they must conform to the WAPI standard proposed as a Chinese standard, at least domestically .This would require an agreement with domestic Chinese companies, including ZTE and Huawei, which for this technology hold strong Intellectual Property Rights IPRs in China. The US government is obviously very eager to delay the Chinese rules and persuade the Chinese government to change its requirements. A tentative agreement on this issue might indicate that China is buying time for its own $3 \mathrm{G}$ system to become fully operational and commercially viable before it offers licenses to mobile operators.

Another sensitive area is open-ware software where Japan and China have common interests. China wants a Linux version for Chinese language. Although, China, Japan and Korea have different interests there are prospects for cooperation in East Asia that could reduce the market dominance of Microsoft.

\section{Creating and using brainpower - The Role of Universities}

The university system in particular as well as education in general has received great attention as a fountain well for China's future as a knowledge-based economy. Universities have undergone dramatic changes in recent years and it is still too early to fully judge their performance, which must be assessed with regard to undergraduate teaching, graduates studies and research. Universities in China have until recently not been involved in advanced research and graduate studies were only introduced after major reforms started in the late 1970 s.

The combined effects of a rapid increase of enrollment and a major restructuring of universities will require several years to fully lighten the burden of such changes. The annual enrollment of students in regular institutions of higher education was only 400,000 in 1978 and dropped to less than 300,000 the following year which corresponded to about $1.5 \%$ of those entering secondary schools in the same year. 
The enrollment in higher education increased rapidly after 1998 with 1,000,000 new students, and the intake expanded to 3.2 million in 2002 which equals ten per cent of the intake in secondary schools the same year. Total enrollment in Chinese universities had by 2002 reached more than 9 million and continues to increase. More than one third of all university students study engineering and including science students the share is close to $40 \%$, and increasing. Thus, Chinese universities will in the predictable future every year graduate at least one million students in science and engineering, the latter with a focus on electronics.

The number of students enrolling as postgraduates has undergone a similar and also very dynamic expansion from a total intake of some 10,000 in 1978 to more than 200,000 in 2002. The number of students having completed postgraduate degrees reached 80,000 in 2002 , with a total enrollment of 500,000 in the same year. At the same time 125,000 Chinese were enrolled in postgraduate studies at overseas universities which shows that presently one out of every five Chinese postgraduate students are pursuing their studies abroad.

In 1997 China embarked on an ambitious plan reform that should bring a number of its universities into world leading positions during the coming century - the National 211 Project ${ }^{6}$. Selection of one hundred universities is expected to create a necessary focus on higher education to receive special attention and favorable funding. Simultaneously many universities merged into more comprehensive entities and are recently governed only by the Ministry of Education. This is a reversal of the reform in 1952 when China adopted a model for higher education from the Soviet Union which led to dividing and dispersing a large number of units. For example School of Sciences and School of Law and Liberal Arts at Tsinghua University were transferred to Peking University while an opposite transfer was made for the Engineering School of Peking University. The result in Peking was that Peking University became focused on social sciences while Tsinghua after the reform only contained engineering departments.

At the same time almost all ministries were given the direct responsibility of higher-level training to meet their specialized needs and established their own universities and colleges. For example, the Ministry of Post and Telecommunications established its own university by merging two departments from Tianjin University and another one from Chongqing University. Subsequently the ministry required four universities in different locations of which Beijing remained prominent. The latter has now become Beijing University of Post and Telecommunications (BUPT) and is like its parallel UPTs in other locations also under the direct control of the Ministry of Education.

Merging universities in China was aimed to achieve a number of objectives, aside from giving the Ministry of Education full control of higher education. First, major universities were given the task to upgrade teaching and facilities of lower-tier colleges. Second,

\footnotetext{
${ }^{6} 211$ stands for the objective of bring a number of Chinese universities into a Global One position in the $21^{\text {st }}$ century
} 
many mergers were aimed to provide complementary strengths. Finally, the changes were also done to reduce staff and overall administrative costs.

The Zhejiang University that came into being in 1998 was created out of the former Zhejiang University that was established in 1928 as University of Medicine and Zhejiang University of Agriculture. During the changes that took place in the early 1950s the School of Liberal Arts and other parts were removed from Zhejiang University to be included in the Zhejiang Normal College that was merged with Hangzhou University in 1958. The present Zhejiang University is included into the list of universities in the 211 Project and is expected, in 2017, to rank among leading universities in the world. In 2003 there were 41,000 full-time students at Zhejiang University, including 30,000 undergraduates, 8,000 master degree students and 3,200 $\mathrm{PhD}$ candidates. There are also nearly 38,000 students enrolled in vocational education courses.

Project 211, the national program for higher education, is mainly oriented to economic development in China and emphasis will be given to support institutions and key disciplinary areas which are closely related to "pillar sectors of industry" where highlevel professional manpower is needed. Priority will be given to some 25 universities which have a concentration of critical disciplines. These universities, which include the major institutions of higher learning in Beijing and Shanghai, are expected to reach high international standards in both teaching and research and become models for other universities in China. An underlying objective is to break away from the narrow disciplinary orientation that existed in the former university system, to broaden the coverage of various disciplines and foster the emergence of cross-disciplinary teaching and research.

The sudden increase of university training, if maintained and successful in terms of quality, will have two important effects - one inside China and the other one in the global economy. In 2002 alone, about 20 million new workers entered the employment market in China, but half of them had only received junior middle school education or less. Currently, a mere 5 percent of China's whole population has received higher education, a figure that is far lower than the average level in developed countries. However, the upsurge in higher education has had the result that students after having completed their university studies can no longer expect to freely choose among job opportunities and will see salary levels shrink compared with only a few years ago. The second consequence is that China will domestically offer an increasing pool of young and educated university graduates who will be available in a job market that already has a well developed industrial, technological and logistics infrastructure in many places all over China. Assuming that universities will continue their expansion in engineering and science at reasonable high quality levels China will increasingly be competing in brainpower rather than in labor-intensive production.

An obsession with commercializing university research has apparently created a conflict of interest as campuses at many colleges have become cradles of entrepreneurship, and new technologies are being raised into business ventures at an increasing rate. A number of incubators have taken the form of campus-based science parks. Peking University 
Science Park is one of these. In the past ten years, it has aided the growth of more and more start-ups. In 2000, 300 projects were evaluated, of which 30 were selected for incubation. Altogether, 400 businesses currently have operations in the park, 80 per cent of which are high-tech enterprises, although critiques argue that many campus companies have little that is high-tech about them.

However, China's major universities have produced some of the best-known names in the technology sector. Peking University Founder Group Corp came into being in 1986 and now has total assets of RMB6,000 million, with shares in 17 other companies and a controlling stake in four listed companies. Its core business has diversified from developing word processing software into hardware, Internet-related products and systems integration. A non-profit school system and its highly specialized teaching and research may not always resist the temptation of the business world, and researchobsessed scholars and market-oriented managers usually have very different perspectives.

\section{National Programs - National Science and Technology Policy}

The People's Republic of China has throughout its history always given a great deal of attention to science and technology which until the early 1980s remained completely within the government domain. Nowadays, the corporate sector has officially taken on a major portion of R\&D in China, although most research-intensive companies are stateowned enterprises or maintain close links with the state sector. However, government programs and initiatives remain important while a private sector is growing in importance to fund and implement R\&D.

Since the beginning of the reform period China has launch five major science and technology programs. The first one was the Key Technologies R\&D Program that was started in 1982 to serve the mainstream of industrial development by concentrating resources on technologies that were urgently needed for industrial upgrading and economic development - its contents evolving as the economy advanced. The next was the Spark Program in 1986 to develop the rural economy through science and technology and to initiate technological changes in village-and-town enterprises (VTE). Only a little later followed the High-Tech Research Development Program (863) that was launched in March 1987. This program coincides in time with initiatives in Japan and the EUREKA program in Europe that were launched in response to the Strategic Defense Initiative (SDI - Star Wars Initiative) in the US.

The Chinese leadership realized that China and its manufacturing units would increasingly face fierce international competition. The origin of the 863 program can be linked to a report with the title "Suggestions on Tracing the Development of World Strategic High Technology" - from 1986 March that gave the program its name. The report, written by three researchers was submitted to State Council and immediately submitted to Deng Xiaobing. The original report became the platform for in-depth and hurried deliberations and resulted in an operational report - The Report on R\&D Plan on 
High Technology. The main mission of the 863 Program was monitoring the international level in advanced technologies, and proposing fitting national schemes. An intermediate aim was reducing the gap between China and developed countries in several important fields and achieving breakthroughs in fields where China holds a comparative advantage.

Next came the Torch Program that was launched in 1988 with the specific objective to develop new-technology industries in China. It was implemented by the Ministry of Science and Technology after approval from the State Council. The Torch Program included a number of activities, aside from a general mandate to provide a legal and organizational environment for the development of high-tech industries. First, the program was given the responsibility to establish new high-tech industrial development zones, where the objective was to convert R\&D into successful industrial production. Second, the program is also responsible for establishing services centers to support high technology development. Third, the program was supposed to establish torch projects in high technology enterprises and enterprise groups that could successfully venture into areas such as new materials, biological engineering and electronics.

A more recent program is the National Key Basic Research (973) Program that was launched in June 1997 and was designed to stimulate research that would result in original innovations and to provide support for future development, with a perspective on 2010. The program is supposed to establish a number of scientific engineering projects of significance for long term development of the Chinese economy and society.

All five programs are still operational, although their nature has been modified and the new projects introduced as earlier ones have been completed. The 2020 Science and Technology Plan to be announced towards the end of 2004 is likely to provide and overall framework for the all programs already mentioned.

The Key Technology R\&D Program of 1982 has its present focus in information technologies and biotechnology. The Spark Program with its attention to local economic development supports a large number of technical projects that use rural resources, need small amounts of investment, give early benefits and use appropriate technologies. The program is also creating demonstration zones to stimulate comprehensive regional development and furthermore develops regional industries that have their basis in a comparative advantage of regional resources. The Ministry of Science and Technology has the overall responsibility for the program while most management is decentralized to province, district and county levels. The Spark Program has attracted attention in many countries and its experience has been utilized by various international organizations including the World Bank.

The National High Technology Research and Development Program of China -863 Program - has the aim of advance the country's international competitiveness and improve overall capability of R\&D in high technology. The program covers a substantial number of research topics which are selected from eight priority areas such as biotechnology, information, automation, energy, advanced materials, marine, space and laser fields. MOST is responsible for all areas except the last two. China officially reports 
that its ability to join the international human genome sequencing project had its roots in an earlier 863 project.

The Torch program under MOST has five main cores which include the creation of environment for the development of new high/tech industries, establishing development zones for such industries which should also serve as windows to the outside world, internationalization of such industries through cooperation with foreign partners, training and attracting talents to raise technology and management mastery of high tech industries, and support of projects which should serve as the starting point and provide the basis of the Torch program. Key fields include new materials, biological engineering, electronics and information, opto-electronics, energy-saving and environmental protection.

The Basic Research Program, also known as the 973 Program is China's ongoing national basic research program which came into existence in June 1997. Many of its projects have its roots in research activities which have initially been supported by the National Natural Science Foundation or other funding agencies. A major objective is to create and fund structures that can efficiently implement basic research into useful results that meet major strategic needs in China. The focus is on original innovations and to improve China's capabilities in a global context, and program has singled out four major tasks. First, the 973 should conduct multidisciplinary research and provide scientific and theoretical foundations to solve important scientific issues that China is facing in the intermediate and long-term future. Related to this the program should engage in explorative research to advance the knowledge front. To meet the first two objectives the program is supposed to cultivate outstanding scientists who have creative capability and who can tackle challenging research tasks. Finally the 973 program is also responsible for the creation of interdisciplinary research centers responsible to carry on projects of high national priority.

The 973 program not only absorbs the largest investment ever made by the central government in research and development but also includes some of the country's largest $\mathrm{R} \& \mathrm{D}$ projects, outside the defense and space sectors. MOST that is managing the program suggests that its implementation has had a remarkable impact on the scientific and technological community in China and greatly boosted the rapid improvement of China's international competitiveness. The program has in a major way involved senior researchers belonging to the Chinese Academy of Science (CAS) and the Chinese Academy of Engineering (CAE), and also encouraged overseas Chinese researchers to join many projects. The program has also provided post-graduate training for a large number of students.

Previous projects have included material research on carbon nanometer pipe arrays. Ongoing research includes the basic study of super-high-density, super-high-speed optical information storage and processing, and basic research of novel devices and novel processes of system on chip (SOC). The objective of this project is to solve the basic problems of device structure, device modeling and simulation, key process and reliability for semiconductors that realize features in the range of 20-50 nanometers. The long-term 
ambition and expectations is that China will take a leading position not only in the manufacture of advanced semiconductors but also in their further development.

These five programs are to develop different parts of the Chinese economy and provide support and funds at various levels of scientific and technological sophistication. Such national programs in China, as well as in any other country, undergo changes and naturally encounter obstacles and failures. However, there is little doubt that they have made a great contribution to the reform of R\&D system in China which is still not completely transformed from the straitjacket of the earlier planned-economy times. In this process big programs have created new interfaces among various sectors of the economy and between research institutes for which CAS still plays a dominant role in major fields of basic research.

However, there can be no doubt that technology will for some time continue to play a dominant role in China's S\&T strategy which was outlined in 2003 in a speech by Chinese Minister of Science and Technology ${ }^{7}$. At the time he stated that China should follow seven major development strategies to become successful in the $21^{\text {st }}$ century.

First, China should adopt a leaping development strategy to accelerate its competitiveness in IT industries by developing new operational systems with associated software platforms and advanced CPU chips. In biotechnology China should focus on functional genome, bioinformatics, bioengineering medicine, and biogenetic seed breeding - to be recognized in the international biomedical industry. Second, China should boost its capacity for original innovation and move away from the country's earlier emphasis on copying proprietary innovations and establish evaluation systems that support this objective. Third, China should improve its capability to integrate and manage National R\&D resources, and national S\&T programs should have an explicit emphasis on disciplinary and interagency cooperation with a focus on the development of products and industries.

Fourth, China should speed up its high-tech industrialization that will include the reform in national high-tech parks, supporting small and medium enterprises and providing needed support services.

Fifth, China will use IT to support the industrialization process which should develop and diffuse high performance computer environment, and create common information technology systems particularly in areas such as banking, insurance and manufacturing.

Sixth, China will promote international S\&T cooperation and provide support for Chinese scientists to actively participate in global large-scale science projects, and encourage multinational companies to invest in $\mathrm{R} \& \mathrm{D}$, and using imported technology and personnel closely integrated with FDI that has in the past played such an important role in China's economic development.

\footnotetext{
${ }^{7}$ Xu Guanhua, Speech on Technology Strategy, Closing Ceremony of the Ministerial Forum on Industrial Policies of China, Beijing International S\&T Industries Fairs, September 15, 2003
} 
Finally, China will improve its human resources strategy to establish a system which is open, competitive and giving more weight to personnel costs in the total R\&D expenditure. China will be paying more attention to the development of human resources and will enhance the import of top notch people from overseas on a selected basis.

\section{Global Rivalry - Competition and Cooperation}

China has become a major player in global trade and its comparative advantage in a number of industrial sectors has given its manufacturers a dominant position for a number of goods. China's industrial advantage lies in its almost unlimited supply of lowcost labor with increasingly higher technical skills that has become available in a large number of clusters, particularly in coastal areas. These clusters are served by good transportation, telecommunications and logistics services which enable close and efficient interaction with global markets.

Although China still enjoys a strong comparative advantage in the manufacture of more traditional labor-intensive products, more striking is the country's large-scale entry as the foremost supplier of almost all electronics goods. This includes not only traditional color TV, and household appliances but also DVD players, notebook computers and mobile handsets. The role of China's manufacturers was initially limited to final assembly for which low-cost high-skilled labor was a key factor while most components were imported, but it is likely to change in quite foreseeable future.

The rapid entry of China into the world trade system to become a major supplier of shoes/garments and electronics is forcing other countries to change their export strategies. This has become very evident, particularly in developing countries that have realized that they must rapidly adjust to a situation that is undergoing constant change. However, effects are also reaching industrialized countries where we can see an earlier comparative advantage in advanced components and subsystems being eroded. Chinese companies are moving up the ladder of industrial competencies in a growing number of technological fields.

The benefit is coming from being embedded in clusters, or competence blocks, that are not only closely linked locally, but also throughout the country and internationally. This phenomenon is also fuelled by decisions of multinational companies that are lured to locate more of value-added production in China, being attracted not only by manual labor but also by brainpower available at low costs. A further attraction lies in the rapidly expanding domestic market. As a result increasingly large shares of production chains for advanced products are being transferred to China. This is causing serious concern in Taiwan, Korea and Japan that fear that their economies will soon suffer from serious industrial hollowing-out, and recently such concerns have also been raised in the US.

China has, as a developing country, has become a natural site not only for final assembly but also for manufacturing parts. However, large international companies usually control the final production into complete sets of advanced equipment. This process would previously for most advanced and heavy machinery been totally integrated in one 
physical location, almost always in an industrialized country. The dissolution of integrated production processes - not only for electronics products - has greatly facilitated the entry of companies in China to get involved. Chinese companies are thereby acquiring skills and technology by expanded participation in the production of large scale equipment for global markets.

At the same time China's rate of economic development has remained high year after year. A favorable budget situation has enabled the government to fund a number of foresighted programs in science and technology. Although not always successful they have in many fields acted as catalysts and contributed to lifting the country out of its earlier technological backwardness. More and more Chinese companies, although still few in numbers, have become research-intensive and will soon challenge competitors in global markets. As a consequence industrialized countries no longer see China as a challenger from the developing world but increasingly as a competitor. There are prospects, however, that China may become potential collaborator in many fields of advanced science and technology.

Since the late 1990s the United States has with increasing concern been watching China's strategies and progress in both civilian and military science and technology. It appears that the European Union has come to view China strategically less as a competitor and more as a collaborator for a number of advanced technologies. Korea and Japan and other countries perceive their economies to become increasingly integrated with China and have with mixed feelings been prompted to further advance their scientific and technological prowess to stay ahead of China.

There is little doubt nowadays that US-China relations are undergoing structural and fundamental changes. China has been able to achieve much more rapid development of industrial capabilities than any other developing country. The apparent ability of the Chinese economy to quickly and efficiently integrate various strands of technological inputs is not only advancing its commercial success but also enables China to radically improve its defense technologies. Underlying this change is an expanding and open market for $\mathrm{R} \& \mathrm{D}$ required in high-tech industries and an increasing willingness of foreign companies to make substantial R\&D investments in China.

At a US Congress hearing in the autumn of 2003 the following factors were highlighted ${ }^{8}$. First, the driving force behind the globalization of $R \& D$ is the need for commercial ventures to increase the value-added for goods and services. Thus, design as well as R\&D is often most efficiently done in close proximity to production bases. This provides a strong impetus to move R\&D to follow production, although advanced and basic research is generally maintained within the home base.

Second, multinational companies no longer limit their R\&D investments to industrialized countries in Europe and Asia. During the past couple of years China has in this respect

\footnotetext{
${ }^{8}$ Commission on US-China Economic \& Security Review, Testimony by Kathleen A. Walsh (The Henry L. Stimson Center), Hearing on China's Industrial, Investment and Exchange Rate policies: Impact on the U.S., Panel III - China's Investment Strategies, September 25, 2003
} 
taken on a prominent role offering a number of attractive sites for R\&D investment. Third, the ongoing revolution in information communications has made IT technologies all-pervasive. This has given global companies an almost unrestricted choice of locations for sophisticated technologies and drastically reduced the hurdles of locating in China the manufacture of technologically complex products, including R\&D. China has in an impressive way taken good advantage of these international dynamically evolving assets that have become available during the past few years.

Too often repeated China has also benefited from its future enormous market potential and its policies and programs to capture the emerging global possibilities. By expanding its human resources and identifying "pillar industries" for the future China has become exceptionally well-positioned to exploit the global dynamics in research and development.

China in October 2003 successfully completed its first manned space flight and subsequently announced that the country will undertake major efforts in space research and development. This came as no surprise to the world as China had for a number of years given great publicity to its space efforts. However, China's space efforts and the success of its first manned space flight is likely to have given an additional boost to the US decision to announce in January 2004, ahead of the State of the Union address by the President, a moon colony plan. The objective is to establish a permanent human settlement on the moon and to set a goal of eventually sending Americans to Mars.

China has announced that it aims to launch 10 satellites in 2004 while preparing for its second manned spaced flight. Although not specifically singled out in relation to China apparently the US wants to maintain a lead, and a Senate hearing includes the following statement". "US policymakers must not sacrifice funding for science and technology to other priorities such as homeland security; both are essential to long-term US national security interests. Funding levels must also increase over time if the United States is to remain economically, technologically, and militarily competitive."

The hearing statement argues that China has greatly benefited from the globalization process which has rapidly opened up new sources of technology and facilitated technology transfer to create an advanced industrial and knowledge-based economy, in considerably less time than under circumstances that existed only a few decades ago. Thus, it is stated that "the challenge it poses for US policymakers is not how to prevent China's technological advancement, but how to stay ahead of it" ${ }^{\text {"10. }}$.

\section{China - A Knowledge Economy}

Every month a book is appearing in China, Japan and the West that tries do portray China as a future knowledge-based economy. All of them testify that economic growth has been remarkable over the past decades with an annual average of close to 10 per cent. They

\footnotetext{
${ }^{9}$ Walsh, A. Walsh, Hearing on China's Industrial, Investment and Exchange Rate Policies: Impact on the U.S., Senate Commission on US-China Economic \& Security Review, September 25, 2003

${ }^{10}$ ibid.
} 
also mention that half of China's high-technology exports include not only consumer electronics but also computers, telecommunications and office equipment for which China is presently highly reliant on imported electronic components. This thriving trade in high-technology has a strong basis in a large number of multinational enterprises that operate large-scale affiliates in China. An OECD report tells that foreign affiliates of multinational enterprises located in China, show low turnover per employee compared with foreign affiliates in Singapore or Hong Kong. This would indicate that multinationals are still using China for the production of low-technology goods ${ }^{11}$.

Any nation desiring to become a knowledge-based economy must in crucial ways develop its human resources and provide infrastructures to fully exploit the talents within its borders. China has during the past ten years dramatically increased the number of students in tertiary education and provided more funding for R\&D, not only in absolute terms but also in relation to its GDP. Traditional indicators, such as patents, still suggest that China is far from reaching its goal of becoming a knowledge-based economy. However, using signs of dynamic changes within industrial sectors and emerging competencies in a number of research fields brings forward a more encouraging scene.

In many locations in China one can find an environment with young and mobile entrepreneurs, a multicultural mixture of people drawn from different parts of China, overseas Chinese, and visitors from a number of countries. Whatever direction China chooses for its national structure of S\&T its future in R\&D management lies in its entrepreneurial urban middle class for which the government must create good institutions, resources and infrastructure.

The participation in a global innovation system (GIS) has recently become highly appraised. It shows itself for example in the increasingly close relations with the European science community. China has reached an agreement to become a full member of the Galileo Project. This is carried out within the $6^{\text {th }}$ Framework Program and will involve close collaboration with the European Space Agency giving China access to future advanced satellite technology and systems. Another example is China's decision in 2003 to become a full member of the ITER fusion project, which has even created a geopolitical conflict as China, Russia and EU opted for France as the location for the major ITER laboratory while the US, that joined the project after China decided to become a member, has strongly argued that Japan should be given this responsibility.

China in a limited number of areas has clearly demonstrated its capability in Advanced Technology Industries (ATI) which reflects spillover effects from defense programs, although now supported through civilian initiatives of a nationwide character. The nation's strength in labor-intensive industries (LII) is continuously demonstrated to the rest of the world. However, China still remains weak in industrial sectors such as semiconductors - not only in advanced manufacturing facilities but also in the development of such as devices and many other advanced components that are needed in

\footnotetext{
${ }^{11}$ An Emerging Knowledge-Based Economy in China?, Indicators from OECD Databases, STI Working Paper 2004/4, OECD, Paris April 2004
} 
basically all kinds of electronics products. China's share of world's software engineers is still miniscule although China will soon deliver some 50 per cent of the world's consumer electronics products.

Thus China needs a much stronger basis in technology-intensive industries (TII) and aims to achieve this through its manpower development combined with TTI infrastructure and strong national efforts to develop innovative technologies. If realized we will in the intermediate future recognize a China that might simultaneously show extraordinary strength in ATI, LII and TII. This would categorically challenge the "flying geese pattern of development" where latecomer nations would just follow the leaders and only gradually move up the chain of technological sophistication. China might upset our concept of structural transformation by concurrently being able to compete on all fronts.

\section{Bibliography}

Accelerating Innovative Pharmaceutical Research and Development in China: A Case Study, International Federation of Pharmaceutical Manufacturers Associations (IFPMA), Geneva, February 2003, 38 pp

An Emerging Knowledge-Based Economy in China?, Indicators from OECD Databases, STI Working Paper 2004/4, OECD, Paris April 2004

Cao, Cong, China,s Scientific Elite, RoutledgeCurzon Studies on China in Transition, 2004

China as an Emerging Regional and Technology Power: Implications for U.S. Economic and Security Interests, Hearing before the U.S.-China Economic and Security Review Commission - February 12-13 2004, 217 pp

China Science and Technology Indicators 2002 - The Yellow Book on Science and Technology Vol. 6, Ministry of Science and Technology, Beijing 2003

China Statistical Yearbook 2003, National Bureau of Statistics, Beijing 2004

China Statistical Yearbook on Science and Technology, China Statistics Press, Beijing 2003

China Statistics Yearbook on High Technology Industry, National development and Reform Commission, China Statistics Press, Beijing 2003

Commission on US-China Economic \& Security Review, Testimony by Kathleen A. Walsh (The Henry L. Stimson Center), Hearing on China's Industrial, Investment and Exchange Rate policies: Impact on the U.S., Panel III - China's Investment Strategies, September 25, 2003

Dahlman, Carl J, \& Aubert, Jean-Eric, China an the Knowledge Economy - Seizing the $21^{\text {st }}$ Century, The World Bank Institute, Washington D.C. 2001

Guo, Kesha, China's Industrial Development Strategy; Policy Options in the New Era, Social Sciences in China, 2004 (forthcoming)

Howell, Thomas R. et al., China's Emerging Semiconductor Industry - The Impact of China's Preferential Value-Added Tax on Current Investment Trends, Prepared by Dewey Galantine LLP for the Semiconductor Industry, Washington D.C., October 2003 
Meyer, Marshal W. \& Lu Xiaohui, Managing Indefinite Boundaries: The Strategy and Structure of a Chinese Business Firm, Management and Organization Review (2004) 1:1 1-30

Naughton, Barry, The Information Technology Industry and Economic Interactions between China and Taiwan, conference paper (CERI: New Information Technologies and the Reshaping Power Relations: An Approach to Greater China's Political Economy), forthcoming in conference volume edited by Francoise Mengin

Sigurdson, Jon (Ed.), Knowledge Systems and Their Global Interaction, Conference 2930 September 2003, Summary of Papers, ISBN 91-975118-0-3, Stockholm, April 2004

Suttmeier, Richard P. \& Yao, Xiangkui, China's Post-WTO Technology Policy: Standards, Software and the Changing Nature of Techno-Nationalism, The National Bureau of Asian Research, NBR Special Report No. 7, Seatttle, May 2004

Zheng, Yongnian, Globalization and State Transformation in China, Cambridge University Press, 2004 